\title{
APLIKASI MEMBRANE BIOREACTOR (MBR) UNTUK PROSES DAUR ULANG AIR LIMBAH
}

\author{
Membrane Bioreactor (MBR) Application for Wastewater Recycle \\ Oleh: \\ Taty Hernaningsih \\ Pusat Teknologi Lingkungan, BPPT
}

\begin{abstract}
Abstrak
Jumlah penduduk yang berkembang pesat menyebabkan bertambahnya kebutuhan air bersih sedangkan disisi lain keadaan ini mengakibatkan makin meningkatnya jumlah air limbah yang dihasilkan. Instalasi pengolah air limbah telah dibangun di beberapa kota besar di Indonesia untuk mengatasi masalah pencemaran, Namun instalasi pengolahan air limbah ini hanya dapat mengolah air limbah untuk mengatasi pencemaran lingkungan tanpa dapat mengatasi kekurangan air bersih masyarakat. Oleh karena itu untuk mengatasi permasalahan yang ada maka perlu dipertimbangkan adanya pengolahan lanjutan berupa unit pengolahan daur ulang air limbah terhadap instalasi pengolahan air limbah yang ada. Salah satu teknologi yang dapat dikembangkan untuk keperluan ini adalah dengan sistem Membrane Bioreactor (MBR) yang sudah banyak diaplikasikan sebagai unit lanjutan dari pengolahan IPAL dan berfungsi sebagai unit pengolah daur ulang air limbah. Sistem MBR ini mempunyai kelebihan diantaranya: hanya membutuhkan sedikit lahan, dapat mengolah air limbah dengan debit yang bervariasi dan mengolah kualitas air limbah dengan efisiensi penghilangan polutan yang tinggi. MBR yang diteliti menggunakan membran sebagai filter yang tenggelam di dalam reaktor. Modul membran berupa hollow fiber dengan bahan membran berupa polimer. Penelitian yang telah dilakukan pada pengolahan air limbah dengan kombinasi IPAL konvensional sebagai unit pendahuluan dan pengolahan lanjutan dengan MBR sejak 4 Maret 2014 sampai Juni 2014 dapat disimpulkan bahwa keseluruhan hasil analisa kualitas air olahan kosentrasinya memenuhi baku mutu air bersih yang ditetapkan Permenkes RI N0.416/Menkes/Per/IX/1990, tanggal 3 September 1990. Proses nitrifikasi dan denitrifikasi juga berjalan dengan sempurna sehingga konsentrasi nitrit dan nitrat memenuhi baku mutu tersebut. Selain itu persentase penghilangan logam berat (arsen, cadmium, chrom, selenium, timbal) dapat mencapai 99\%,
\end{abstract}

Kata Kunci: $M B R$, daur ulang air limbah, $B O D_{5}, C O D, H R T$ dan $S R T$

\begin{abstract}
The population is growing rapidly result to increased demand for drinking water while the other side of this situation causes to the increasing amount of wastewater. Waste water treatment plant has been built in several major cities in Indonesia to overcome the problem of pollution. Wastewater treatment plant only treats wastewater to tackle environmental pollution without being able to overcome the shortage of clean water community. Therefore, to solve the existing problems will be considered any further processing with recycled waste water treatment. One technology that may be developed for this purpose is the system of Membrane Bioreactor (MBR). This has been widely applied as an advanced unit of wastewater treatment and serves as a unit of processing recycled waste water. The MBR system has advantages such as: it only takes a little bit of land, can treat wastewater with discharge varying quality and process wastewater with high pollutant removal efficiency. MBR were investigated using a membrane filter submerged in the reactor. Membrane module is hollow fiber with a form of polymeric membrane materials. Research has been done on wastewater treatment with a combination of conventional WWTP as preliminary and advanced processing unit with MBR since March 4, 2014 until June 2014. The effluent quality of result research proved that the treated water quality meets water quality standards are set with Permenkes RI N0.416/Menkes/Per/IX/1990, dated 3 September 1990. The nitrification and denitrification also proceed well so that the concentration of nitrite and nitrate meet the quality standards. In addition, the percentage removal of heavy metals (arsenic, cadmium, chromium, selenium, lead) can reach $99 \%$.
\end{abstract}

Keywords: $M B R$, wastewater reuse, $B O D_{5}, C O D, H R T$ dan $S R T$ 


\section{PENDAHULUAN}

\subsection{Latar Belakang}

Perkembangan jumlah penduduk yang sangat pesat terutama di kota-kota besar di Indonesia menyebabkan makin bertambahnya kebutuhan air bersih sedangkan disisi lain keadaan ini mengakibatkan makin meningkatnya jumlah air limbah yang dihasilkan. Kesadaran masyarakat akan pentingnya pengolahan limbah cair manusia (limbah domestik) masih belum sama dengan kesadaran terhadap pentingnya air bersih. Kurangnya sarana pengelolaan air limbah kota maka banyak masyarakat yang belum mengolah air limbahnya akan membuang air limbahnya ke sungai, laut atau badan air tanpa pengolahan terlebih dahulu. Hal ini akan menimbulkan dampak negatif yaitu pencemaran lingkungan oleh limbah cair domestik terutama di kota-kota besar, khususnya di Jakarta. Berdasarkan penelitian (JICA, 1990) kondisi pencemaran di kota ini makin lama telah menunjukkan gejala yang cukup mengkhawatirkan.

Untuk mengatasi masalah pencemaran di beberapa kota besar di Indonesia telah dibangun instalasi pengolahan dari rumah kerumah rumahrumah melalui saluran perpipaan dangkal (shallow sewer) yang dirangkai dengan tangki septik komunal dengan ukuran besar dan kolam (lagoon)

sebagai instalasi pengolah air limbah, Namun instalasi ini hanya dapat mengolah air limbah untuk mengatasi pencemaran lingkungan tanpa dapat mengatasi kekurangan air bersih masyarakat.

Oleh karena itu untuk mengatasi permasalahan yang ada maka perlu dipertimbangkan adanya pengolahan lanjutan terhadap instalasi pengolahan air limbah yang ada berupa unit pengolahan daur ulang air limbah. Sehingga air olahan dari unit pengolahan air limbah dan daur ulang yang dikembangkan ini dapat digunakan sebagai sumber air bersih, seperti air pengglontor toilet, siram tanaman dan cuci mobil.

Kendala penambahan unit pengolahan daur ulang umumnya membutuhkan lahan yang luas sedangkan di kota-kota besar lahan yang tersedia sangat terbatas. Salah satu teknologi yang dapat dikembangkan untuk keperluan ini adalah dengan sistem Membrane Bioreactor.

Membrane Bioreactor (MBR) merupakan teknologi pengolahan air limbah yang sudah banyak diaplikasikan di seluruh dunia. Perkembangan penggunaan ini makin bertambah banyak sejalan dengan kebutuhan masyarakat. Sehingga kapasitas pengolahan air limbah juga disesuaikan dengan keperluan yang ada, sebagai contohnya kapasitasnya sebesar 5.000 sampai $10.000 \mathrm{l} / \mathrm{jam}$. Pembangunan pengolahan ini malahan sudah ada yang ditingkatkan dengan dengan kapasitas pengolahan sebesar 45.000 I/jam (Chapman S, and Leslie G, 2001).

Teknologi ini lebih baik dari pada teknologi pengolahan konvensional lumpur aktif yang tidak dapat mengolah air limbah dengan debit air limbah yang berubah-ubah. Selain itu teknologi ini juga dapat mengolah air limbah dengan kualitas ar limbah yang lebih buruk dari air limbah yang diolah dengan proses konvensional lumpur aktif.

Meskipun biaya investasi dan operasi dengan kinerja teknologi $M B R$ melebihi dari teknologi pengolahan konvensional tetapi penggunaan $M B R$ ini makin bertambah. Hal ini disebabkan kualitas efluen dari pengolahan daur ulang air limbah sangat baik sehingga dapat digunakan untuk menambah sumber air bersih yang makin lama makin berkurang.

Kajian ini akan membahas tentang aplikasi instalasi pengolahan air limbah domestik yang digabungkan dengan pengolahan daur ulang air limbah dengan sistem Membran Bireaktor (MBR) serta hasil olahannya dapat dimanfaatkan sebagai air bersih.

\section{TUJUAN}

Untuk mengetahui kinerja hasil pengolahan air limbah pada aplikasi Membrane Bioreactor (MBR) sebagai proses daur ulang air limbah yang merupakan proses lanjutan dari instalasi pengolahan air limbah (IPAL).

\section{KAJIAN PUSTAKA}

Proses MBR diperkenalkan oleh akhir 1960an setelah ultrafiltrasi komersial (UF) dan mikrofiltrasi (MF) membran dikembangkan. Proses MBR awalnya diperkenalkan oleh Dorr - Oliver Inc. dan merupakan kombinasi penggunaan bioreaktor berisi lumpur yang diaktifkan dengan loop filtrasi membran crossflow. Membran lembaran plat digunakan dalam proses ini adalah berupa polimer yang berukuran pori berkisar 0,003-0,01 pm (S. Judd, 2006).

Terobosan baru untuk $M B R$ muncul pada tahun 1989 oleh Yamamoto dan rekan kerja yaitu ide merendam membran dalam bioreaktor. Sampai saat itu $M B R$ dirancang dengan perangkat pemisahan terletak eksternal ke reaktor (sidestream $M B R$ ) dan mengandalkan tekanan yang tinggi untuk melakukan filtrasi.

Pada prinsipnya Membrane Bioreactor (MBR) merupakan suatu sistem pengolahan air limbah yang mengaplikasikan penggunaan membran yang terendam di dalam bioreaktor. Proses yang terjadi di dalam bioreaktor merupakan kombinasi proses membran untuk pemisahan biomassa. Membran dalam hal ini juga menggantikan peran kolam 
sedimentasi untuk memisahkan padatan dan cairan pada teknologi konvensional (lumpur aktif).

Penggunaan membran menghasilkan kinerja pemisahan menjadi lebih baik karena pemisahan tidak lagi dibatasi oleh kondisi hidrodinamik lumpur seperti waktu tinggal lumpur (SRT, sludge retention time), waktu tinggal cairan (HRT, hydraulic retention time) serta laju pembuangan lumpur. Bedanya, pada MBR proses pemisahan lumpur dilakukan menggunakan membran sementara pada proses lumpur aktif pemisahan lumpur dilakukan secara gravitasi di dalam tangki pengendap.

Teknologi ini lebih baik dari pada konvensional lumpur aktif yang tidak dapat mengolah air limbah dengan debit air limbah yang berubah-ubah Selain itu teknologi ini juga dapat mengolah air limbah dengan kualitas ar limbah yang lebih buruk dari pada air limbah yang diolah dengan konvensional lumpur aktif.

MBR mempunyai banyak keuntungan diantaranya, meliputi:

- Tidak diperlukan bak pengendap kedua dan proses filtrasi, sehingga mengurangi jumah bangunan pengolahan. Dalam kondisi tertentu, sesuai dengan peraturan yang berlaku dengan kualitas efluen yang cukup baik maka tidak diperlukan digester dan desinfeksi dengan ultra violet.

- Tidak seperti bak pengendap pada proses lumpur aktif yang dalam pemisahan lumpurnya perlu karakteristik tertentu sedangkan proses ini tidak tergantung dari karakteristiknya sehingga volume untuk aerasi bisa dikurangi.

- Dapat dirancang untuk long sludge age, sehingga tidak tergantung dari jumlah lumpur yang dihasilkan.

- Pengolahandengan Mikrofiltrasi (MF) /

- Ultrafiltrasi UF menghasilkan kualitas efluen yang baik sehingga dapat digunakan sebagai sumber air daur ulang.

- Hasil pengolahan dari MBR tidak menimbulkan polusi kebisingan dan bau sehingga dapat dibangun di daerah perumahan.

- Membutuhkan lahan sedikit sehingga cocok untuk mengolah air limbah domestik di daerah perkotaan.

Dalam proses $M B R$ beberapa faktor yamg mempengaruhi filtrasi adalah karakteristik membrane, karakteristik lumpur dan kondisi operasi. Secara rinci uraian dari faktor ini dapat dilihat pada gambar 1.

\subsection{Klasifikasi Membran}

Klasifikasi membran yang banyak digunakan untuk proses ini adalah mikrofiltrasi (MF), ultrafiltrasi (UF), nanofiltrasi (NF), reverse osmosis
$(R O)$, electrodialisis (ED) dan deionisasi elektro (EDI). Masing-masing membran mempunyai kapasitas penyaringan sebagai berikut: 100 sampai $1000 \mathrm{~nm}$ untuk MF, 5 sampai $100 \mathrm{~nm}$ untuk UF, 1 sampai 5 $\mathrm{nm}$ for NF, dan 0.1 sampai $1 \mathrm{~nm}$ untuk RO yang dapat dilihat pada gambar 2 .

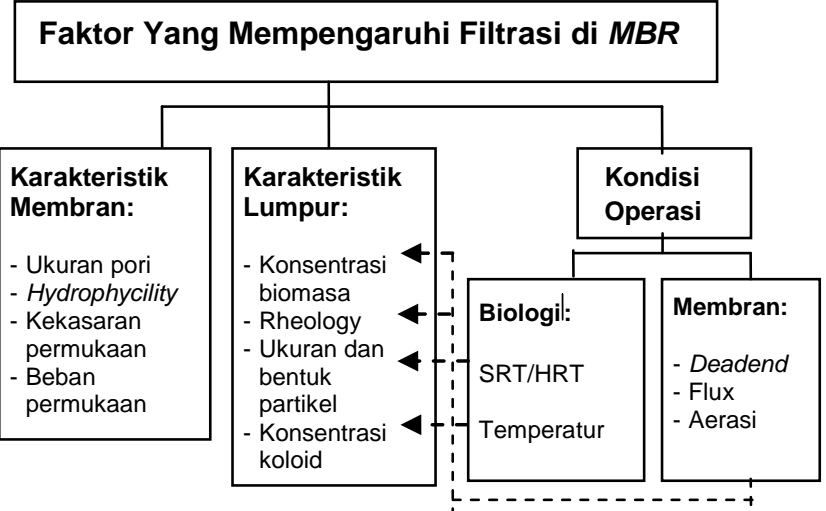

Gambar 1. Faktor Yang Mempengaruhi Filtrasi di $M B R$.

Membran umumnya terbuat dari material plastik dan keramik, tetapi ada yang terbuat dari logam. Material yang sering digunakan adalah celluloses, polyamides, polysulphone, polysulphone dan polymeric lainnya seperti polyacrylonitrile (PAN), polyvinylidene difluoride (PVDF), polyethylene (PE), polyethylsulphone (PES) and polypropylene (PP).

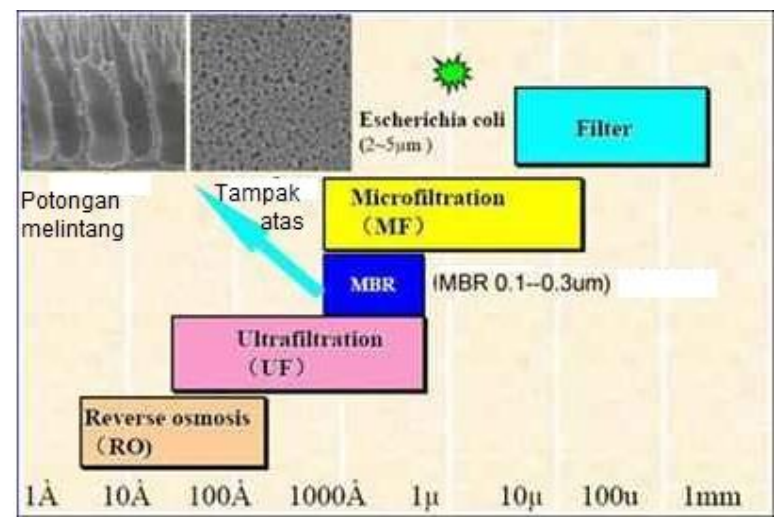

Gambar 2. Klasifikasi Membran.

Ada 5 prinsip konfigurasi membran, yaitu:
1) Hollow fiber (HF)
2) Spriral-Wound
3) Plate-and-frame, contohnya : flat sheet (FS)
4) Pleated filter cartridge
5) Tubular

\subsection{Konfigurasi MBR}

Konfigurasi proses MBR ini bermacam-macam tergantung dari kualitas air limbah yang akan diolah dan 
letak membrane terhadap reactor. Contohnya: proses ini dapat dilengkapi zone anoksik yang diletakkan setelah pengolahan aerobik sebagai cara melakukan denitrifikasi dengan dimensi tergantung dari konsentrasi efluen nitrat dan nitrogen. Selain itu dalam proses ini juga dapat juga digunakan zone anaerobik untuk meningkatkan penghilangan phosphor. berikut :

Jenis konfigurasi proses MBR adalah sebagai

\section{a. Membran Terendam (Submerged Membrane)}

Membran sebagai filter dapat dipasang di dalam bioreaktor utama atau dalam tangki terpisah. Membran dapat berupa sheet datar atau tubular atau kombinasi keduanya, dan dapat menggabungkan sistem backwash secara online yang berfungsi mengurangi fouling dipermukaan membran dengan pompa. Aerasi tambahan juga diperlukan untuk memberikan tekanan air sehingga mengurangi fouling. Dimana membran dipasang di reaktor utama, modul membran dikeluarkan dari kapal dan dipindahkan ke tangki pembersih offline (Cote $P$, Thompson D., 2000).

\section{Influen}

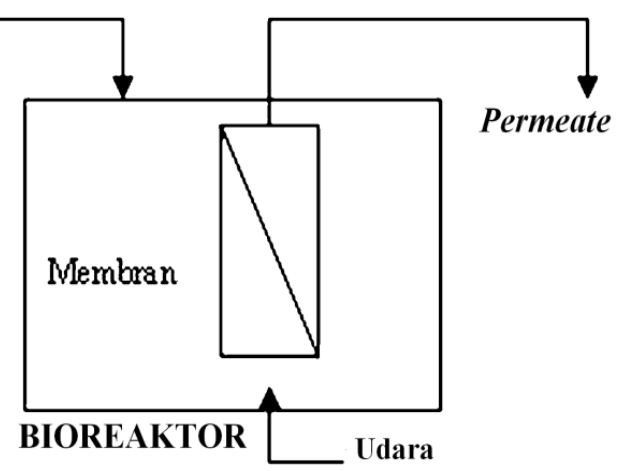

Gambar 3. Submerged MBR

\section{b. Membran Eksternal (Side Stream Membrane)}

Membrane dipasang diluar bioreaktor setelah bioreaktor tersebut. Biomassa dipompa langsung ke modul membran yag dipasang seri dan aliran resirkulasi kembali ke bioreaktor untuk mengatur konsentrasi MLSS. Pembersihan dan perendaman membran dapat dilakukan di reaktor tersebut yang dilengkapi pompa dan pipa yang berfungsi pembersihan.

Dari kedua sistem yang sering digunakan adalah submerged membrane karena energi yang digunakan lebih kecil. Perbandingan kedua sistem tersebut dapat dilihat pada Tabel 1.
Influen

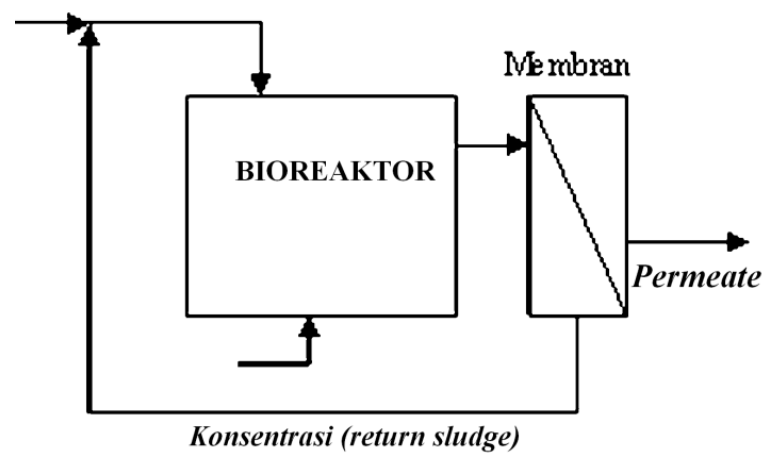

Gambar 4. Side-stream MBR.

Tabel 1: Perbandingan Kondisi Side-Stream Dan Submerged Membrane.

\begin{tabular}{|c|c|c|}
\hline Item & $\begin{array}{l}\text { Side - stream } \\
\text { mebrane }\end{array}$ & $\begin{array}{l}\text { Submerged } \\
\text { membrane }\end{array}$ \\
\hline Merk & Zenon & Zenon \\
\hline Model & $\begin{array}{c}\text { Permaflow Z- } \\
8 \\
\end{array}$ & $\begin{array}{l}\text { Zee Weed ZW- } \\
500\end{array}$ \\
\hline $\begin{array}{l}\text { Luas } \\
\text { Permukaan }\left(\mathrm{m}^{2}\right)\end{array}$ & 2 & 46 \\
\hline Flux $\left(\mathrm{l} / \mathrm{m}^{2} / \mathrm{jam}\right)$ & $50-100$ & $20-50$ \\
\hline Tekanan (bar) & 4 & $0,2-0,5$ \\
\hline $\begin{array}{l}\text { Kecepatan aliran } \\
\text { udara }\left(\mathrm{m}^{3} / \mathrm{jam}\right)\end{array}$ & - & 40 \\
\hline $\begin{array}{l}\text { Energi untuk } \\
\text { filtrasi }\left(\mathrm{kWh} / \mathrm{m}^{3}\right)\end{array}$ & $4-12$ & $0,3-0,4$ \\
\hline Ukuran/Dimensi & Lebih kecil & Lebih besar \\
\hline Biaya aerasi & Rendah & Tinggi \\
\hline Biaya operasional & Lebih tinggi & Lebih rendah \\
\hline Biaya pemompaan & Tinggi & $\begin{array}{l}\text { Sangat } \\
\text { rendah, } \\
\text { kecuali jika } \\
\text { digunakan } \\
\text { pompa hisap }\end{array}$ \\
\hline $\begin{array}{l}\text { Kebutuhan proses } \\
\text { pembersihan }\end{array}$ & Lebih tinggi & Lebih sedikit \\
\hline Biaya investasi & Lebih rendah & Lebih tinggi \\
\hline
\end{tabular}

Sumber: Malia dan Till (2001)

\subsubsection{Efisiensi Penghilangan Polutan COD Dan BOD $_{5}$}

Jumlah mikroorganisme di $M B R$ banyak sehingga tingkat penghilangan polutan dapat ditingkatkan. Hal ini menyebabkan degradasi yang lebih baik dalam jangka waktu tertentu sehingga volume reaktor yang dibutuhkan lebih kecil. Dibandingkan dengan proses lumpur aktif konvensional yang biasanya mencapai 95 persen, 
penyisihan COD dapat meningkat menjadi 96-99 persen pada MBR. Perbandingan proses dan tingkat penghilangan polutan di proses lumpur aktif dan MBR dapat dilihat Tabel 2 (lampiran).

Penghilangan $\mathrm{COD}$ dan $\mathrm{BOD}_{5}$ meningkat dengan bertambahnya konsentrasi MLSS. Pada MLSS di atas $15 \mathrm{~g} / \mathrm{l}$, penghilangan COD tidak tergantung dari konsentrasi biomassa yaitu >96 persen. Sehingga konsentrasi MLSS tinggi tidak dilakukan karena tidak mempengaruhi pertambahan dalam menghilangkan COD (M. Kraume, et.al., 2005).

Seperti di proses lumpur aktif konvensional, hasil penghilangan lumpur menurun pada SRT (Sludge Retention Time) tinggi atau konsentrasi biomassa yang lebih tinggi. Hanya sedikit atau tidak ada lumpur yang dihasilkan pada tingkat pembebanan lumpur dari $0.01 \mathrm{kgCOD} \mathrm{/} \mathrm{(kgMLSS} \mathrm{d)}$ (Canziani, R. et.al, 2006). Dengan adanya batas konsentrasi biomassa, maka ukuran tangki pada proses lumpur aktif lebih besar atau nilai HRT lebih lama.

\subsubsection{Penghilangan Nutrien}

Penghilangan nutrien perlu diperhatikan dalam pengolahan air limbah, terutama di daerah yang sering terjadi eutrofikasi. Dalam proses lumpur aktif konvensional, teknologi yang paling banyak digunakan saat ini untuk penghilangan dari airlimbah kota adalah nitrifikasi dikombinasikan dengan denitrifikasi.Selain itu dengan adanya phosphor dari curah hujan,maka perlu dilakukan dengan proses Enhanced biological phosphorus removal (EBPR) melalui penambahan proses anaerobik. Beberapa karakteristik teknologi MBR dilakukan dengan alternatif kombinasi EBPR dan pasca-denitrifikasi dapat mengolah sehingga konsentrasi nutrient yang sangat rendah (Delgado, S. et.al, 2002).

\subsubsection{Nitrogen}

Efisiensi penghilangan nitrogen sudah dilakukan dalam proses MBR (Canziani, R., 2006). Adanya penambahan sedikit suplai oksigen dan kecepatan nitrifikasi akan memfasilitasi pertumbuhan flok biologis. Proses anaerob denitrifikasi diperlukan dalam menghilangkan nitrogen dalam proses MBR. Nitrifikasi dalam MBR lebih besar dari pada proses konvensional lumpur aktif yang mempunyai waktu retensi lebih lama untuk bakteri bernitrifikasi ( sludge age nilainya tinggi, ratio food/ microorganism nilainya tinggi) dan ukuran flok lebih kecil yang menyebabkan massa transport yang lebih tinggi dari nutrient dan oksigen di dalam flok.

$M B R$ dapat mencapai nitrifikasi sempurna dengan retensi pertumbuhan bakteri autrotrophik yang lambat. Pada beban nitrogen 0,1 dan $3,3 \mathrm{~kg}$
$/ \mathrm{NH}^{3}$.hari, penghilangan ammonia lebih besar dari mempengaruhi 90\%. Penghilangan nitrifikasi dapat dipertahankan pada presentasi tinggi dengan kosentrasi DO lebih rendah $(<5 \mathrm{mg} / \mathrm{l})$ ). Denitrifikasi untuk penghilangan nitrat yang kemudian menghasilkan bermacam-macam gas berupa molekul nitrogen dan nitrogen oksida pada akhir reaksinya dapat bereaksi dengan baik jika:

- $\quad$ aerasi dilakukan secara berkala yaitu dengan adanya hidrodinamik yang menghasilkan area anoksik,

- penambahan pembebanan organik yang tinggi sehingga timbul area anoksik mikro yang membantu pembentukan flok.

Dalam proses aerobik di $M B R$, denitrifikasi dapat dicapai jika sebelum MBR dilakukan penambahan tangki anaerobik dan tangki aerobik yang merupakan sistem konvensional.

\subsubsection{Fouling Di Membran}

Fouling di membran perlu diperhatikan dalam mendesain membran pada sistem MBR. Membran fouling dapat disebabkan oleh partikel yang terbentuk, kontaminasi kimia atau presipitasi. Partikulat fouling terjadi akibat materi dalam limbah cair yang mengumpul pada permukaan membran. Sebagai lapisan menumpuk pori-pori membran dapat memblokir mengurangi fluks melalui membran dan meningkatkan TMP. Partikulat dapat membusuk atau mempersempit pori-pori membran atau melalui pembentukan cake di permukaan. Membran fouling dapat dikontrol melalui pembilasan dengan penggunaan kimia dan pemeliharaan membersihkan secara periodik di tempat (P. Le-Clech, V. Chen, A.G. Fane, 2006).

Back wash dapat dilakukan dengan pembilasan air serta aliran udara atau melalui membran untuk membersihkan pori-pori. Jika membran ini sangat kotor maka diperlukan pembersihan dengan kimia. Sodium hidroksida larutan surfaktan dan bahan kimia yang paling umum digunakan untuk membersihkan, tapi bahan kimia lain seperti asam sitrat, klorin, hidrogen peroksida, atau aluminium bifluoride dapat digunakan tergantung pada pedoman produsen.

Lamanya fouling karena pengendapan mangan dari silika telah diamati dalam beberapa kasus, tetapi secara umum dapat dibersihkan dengan aliran balik (Layson, 2003). Dalam bioreaktor membran ada beberapa langkah tambahan yang diambil untuk mengurangi fouling karena padatan tersuspensi yang tinggi. Gelembung besar aerasi dikeluarkan di bagian bawah membran yang dialirkan secara vertikal di sepanjang serat membran. Selain itu untuk menghilangkan lebih banyak partikel dengan cara meningkatkan waktu pembersihan 


\subsection{Desain Membran dan Alternatif Operasinya}

Desain submerged membrane bioreactor atau bioreaktor dengan membran yang terendam harus dilakukan back flushing untuk mengontrol penghilangan cake dan fouling di permukaan membran, Pemberian udara untuk menghasilkan surface shear dan kecepatan aliran yang dapat melewati membran harus stabil sebesar 1 atmosfer.

Dalam mendesain MBR tergantung faktor SRT dan $H R T$ yang mempengaruhi kinerja MBR

Konfigurasi membrane yang harus dipenuhi bioreaktor ini adalah (Gupta N; Jana N; Majumder C B. 2008) :

1. Hollow Fiber-Capilarry:

- Diamater membran sangat kecil (<1 mm)

- Sejumlah besar membran dalam modul dan unit pendukungnya.

- Densitas 600 sampai $1.200 \mathrm{~m}^{2} / \mathrm{m}^{3}$ (untuk capirlary membrane) sampai $30.000 \mathrm{~m}^{2} / \mathrm{m}^{3}$ (untuk hollow fiber membrane).

- Hasil dari proses selama melewati membran dikumpulkan diluar membran.

2. Plat dan frame:

- Bentuk sederhana dan membran dapat dipindahkan dengan mudah.

- Mirip dengan filter press. - Densitas 100 sampai $400 \mathrm{~m} 2 / \mathrm{m} 3$.

- Membran diletakkan parallel dengan influen saling berhadapan satu sama lain.

Sludge Retention Time (SRT) dapat dinyatakan dalam persamaan di bawah ini (Gupta N; Jana N; Majumder C B. 2008):

$\mathrm{SRT}=\mathrm{V} \cdot \mathrm{X} / \mathrm{Q} \cdot \mathrm{X}=\mathrm{V} / \mathrm{Q}$

dimana;

$\mathrm{V}$ : volume reaktor

$\mathrm{X}$ : konsentrasi biomasa dalam reaktor

Q: debit air limbah yang masuk reaktor

Perhitungan konsentrasi substrat awal (s) dan konsentrasi substrat setelah waktu $t\left(s_{t}\right)$ air limbah dapat dinyatakan dalam persamaan berikut:

$s=K_{s} \mu_{s}-\left(K_{d}+1 / S R T\right) /\left(K_{d}+1 / S R T\right)$

dimana;

$\mathrm{Ks}, \mathrm{Kd}, \mu_{\mathrm{s}}$ : biokinetik koefisien

Untuk menghitung Death Rate Constant $(K d)$ dapat dilakukan dengan persamaan:

$\left.Q / X \cdot V\left(s_{t}-s\right)=(1 / S R T) \cdot(1 / \partial)\right]+[(1 / \partial)]$

dimana:

$\partial$ :koefisien yield

\subsection{Aplikasi Pengolahan IPAL dan MBR}

Berdasarkan pengalaman pada penerapan MBR yang telah diaplikasikan dapat diketahui bahwa sistem membran sangat sensitif terhadap makro fouling oleh kotoran. Adanya kotoran mengakibatkan problem dalam operasi MBR dan malahan akan menyebabkan kerusakan. Untuk mengatasi ini maka perlu dilakukan pengolahan pendahuluan untuk menghilangkan padatan (seperti: padatan kasar yang berupa plastic, biji-bijian, pasir serta minya, lemak dan rambut) yang terdapat didalam air limbah.

Sesuai dengan kondisi tersebut maka unit pengolahan air limbah yang akan dikaji adalah Instalasi Pengolahan air Limbah (IPAL) sistem konvensional yang akan mengolah air limbah sehingga mencapai kualitas air yang dapat diolah lebih lanjut dengan proses $M B R$ dan post treatment (pengolahan lanjutan) yang merupakan unit pengolahan air daur ulang dengan sistem MBR.

IPAL terdiri atas bak pengumpul, bak pemisah lemak dan bak ekualisasi, bak pengendap awal, biofilter anaerob, biofilter aerob, bak pengendap akhir dan khlorinasi. Masing-masing unit pengolahan menghasilkan efisiensi pengolahan dengan konsentrasi penghilangan BOD sebagai berikut:

- Pengolahan dengan bak pengumpul, bak penghilang lemak dan ekualisasi mengolah BOD menjadi sebesar $300 \mathrm{mg} / \mathrm{l}$.

- Bak pengendap awal mengolah air limbah dengan efisiensi penghilangan BOD sebesar $25 \%$ sehingga BOD berkurang menjadi $225 \mathrm{mg} / \mathrm{l}$.

- Biofilter anaerob dapat mengolahair limbah dengan efisiensi penghilangan BOD sebesar 65 - 75\% sehingga BOD menurun menjadi $75 \mathrm{mg} / \mathrm{l}$.

- Biofilter aerob dapat mengolah air limbah dengan efisiensi penghilangan BOD sebesar 65 - 75\% sehingga BOD menurun menjadi $30 \mathrm{mg} / \mathrm{l}$.

- Dengan unit pengendap akhir jumlah BOD di air limbah makin menurun sehingga dapat memenuhi standar baku mutu efluen yang diijinkan untuk dibuang ke saluran kota. Untuk menghilangkan bakteri dilakukan khlorinasi sebelum air dialirkan ke saluran kota.

Sebagian air limbah yang telah diolah di IPAL, diolah lagi dengan sistem post treatment (pengolahan lanjutan) berupa $M B R$ yang dilengkapi dengan blower udara dalam proses pengolahannya serta modul membran. Skema diagram alir ipal dan pengolahan lanjutan $M B R$ dapat dapat dilihat pada Gambar 5.

Unit Membran Bioreactor yang terdiri atas reaktor biologi, membran, pompa, blower dan panel control yang dapat dilihat pada Gambar 6 . 

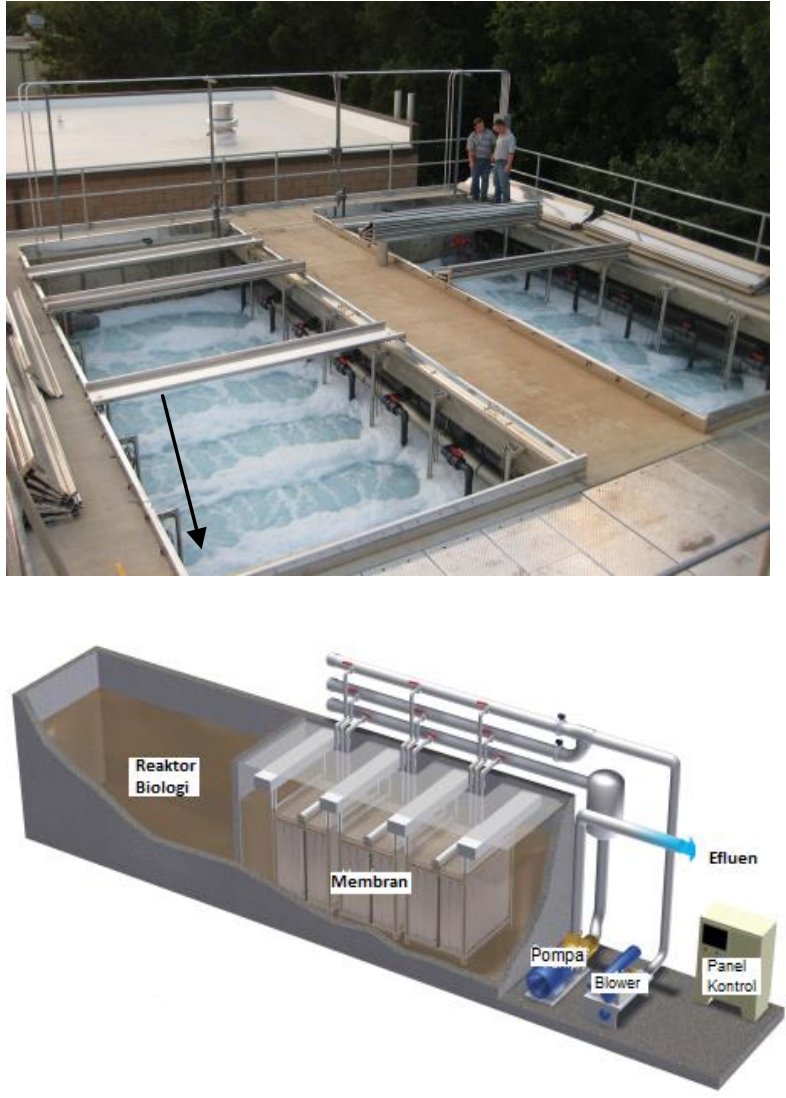

Gambar 6. Membran BioreactorZenon MBR Plant (www.zenon.com)

\subsection{Operasi MBR}

Sistem MBR menggunakan membran berbentuk hollow fiber dirangkai dalam bentuk modul bulat yang melekat pada rak dan dicelupkan kedalam reaktor. Aerasi dan limbah dialirkan kedalam reaktor dengan two-phase air-water jet dari dasar modul. Sistem ini menghasilkan distribusi MLSS yang merata melalui modul dan mencegah mengendapnya padatan di permukaan membrane.

Disarankan supaya proses pengolahan berjalan dengan baik maka jumlah membran yang dipakai sesuai dengan kapasitas dengan air limbah yang dialirkan ke MBR. Untuk keperluan ini maka desain untuk influen dan efluen harus sesuai dengan debit air yang dialirkan. Selain itu desain tanki reaktor sedemikian rupa agar dapat memudahkan untuk mengeluarkan membran jika debit kecil. Hal ini bertujuan supaya energi dapat dihemat dan membran dapat lebih awet jika tidak dipakai terus menerus.

Setiap membran dilengkapi dengan pompa influen supaya lumpur dapat dialirkan ke tangki aerasi. Ini dimaksudkan agar proses mikrobiologi di lumpur tetap aktif dan terjadi penumpukan lumpur di reaktor. Aliran lumpur yang di recycle secara gravitasi menuju sistem aerasi.
Selain itu setiap membran terdapat pompa untuk menyeimbangkan aliran dan backwash sehingga tidak terjadi fouling pada membran. Reaktor ini dilengkapi dengan aerasi dengan turbulensi yang berfungsi untuk proses penguraian organik dan mencegah menempelnya lumpur di permukaan membran. Lamanya aerasi disesuaikan dengan debit dan waktu tinggal di reaktor tersebut serta harus terus menerus pemeberian oksigennya.

Dapat ditambahkan bahwa pembersihan secara fisik dilakukan secara berkala terhadap permukaan membran dan juga pembersihan dengan bahan kimia dengan periodik. Perlunya pencegahan adanya fouling pada membran yang merupakan penyebab penurunan kapasitas pengolahan. Metode pembersihan dikembangkan sesuai dengan penelitian skala pilot. Pembersihan dapat dilakukan setiap minggu atau seminggu 2 kali tergantung dari larutan kimia yang digunakan.

\section{HASIL ANALISA AIR OLAHAN}

Untuk mengetahui kinerja MBR yang berfungsi sebagai unit daur ulang maka telah dilakukan analisa terhadap sampel air yang telah diolah pada unit MBR tersebut tertanggal 4 Maret 2014, 7 April 2014 dan 12 Juni 2014. Sampel air telah dianalisa di laboratorium dan hasilnya dibandingkan terhadap baku mutu yang ditetapkan Permenkes RI N0.416/Menkes/Per/IX/1990, tanggal 3 September 1990. Hasil penelitian dapat dilihat pada Tabel 3.

Berdasarkan hasil di atas maka dapat dilihat bahwa hampir semua parameter kualitas air olahan Membrane Bioreactor dari ketiga sampel memenuhi baku kecuali konsentrasi zat organik 10,1 mg/l pada 10 Maret 2014 yang sedikit melebihi baku mutu yang ditetapkan (10 mg/l). Jika melihat secara keseluruhan hasil analisa kualitas air olahan kosentrasinya ratarata jauh dibawah baku mutu yang ditetapkan.

Proses nitrifikasi dan denitrifikasi juga berjalan dengan sempurna sehingga konsentrasi nitrit dan nitrat dibawah baku mutu. Selain itu persentase penghilangan logam berat (arsen, cadmium, chrom, selenium, timbal) dapat mencapai 99\%, Berarti sistem Membrane Bioreactor dapat dinyatakan mempunyai kinerja yang baik untuk digunakan sebagai teknologi daur ulang air limbah yang dapat memenuhi baku mutu air bersih sebagai air daur ulang.

Dengan hasil air olahan $M B R$ tersebut menunjukkan bahwa hasil olahan pengolahan pendahuluan (pretreatment) dari IPAL yang diletakkan sebelum $M B R$ mempunyai kualitas yang baik karena efluen yang dihasilkan dapat memenuhi standar untuk di olah di MBR. Hal ini mejelaskan bahwa perlu adanya kombinasi pengolahan 
pendahuluan dan MBR agar menghasilkan air daur ulang yang memenuhi baku mutu air bersih.

Tabel 3. Hasil analisa kualitas air olahan $M B R$

\begin{tabular}{|l|c|c|c|c|c|}
\hline Parameter & Unit & $\begin{array}{c}\text { Baku } \\
\text { Mutu }\end{array}$ & \multicolumn{3}{|c|}{ Hasil Penelitian } \\
\hline Fisika & & & $\begin{array}{c}4 \text { Mar- } \\
14\end{array}$ & $\begin{array}{c}7 \text { Apr- } \\
14\end{array}$ & $\begin{array}{c}16 \text { Jun- } \\
14\end{array}$ \\
\hline $\begin{array}{l}\text { Juml.zat } \\
\text { padat }\end{array}$ & $\mathrm{mg} / \mathrm{l}$ & 1500 & 186 & 238 & 258 \\
\hline Kekeruhan & $\mathrm{NTU}$ & 25 & 0,10 & 0,11 & 0,17 \\
\hline Warna & $\mathrm{TCU}$ & 50 & 1 & 1 & 2 \\
\hline pH & & $6,5-9$ & 7 & 7,21 & 7,85 \\
\hline Kimia & & & & & \\
\hline Arsen & $\mathrm{mg} / \mathrm{l}$ & 0,5 & $<0,001$ & $<0,001$ & $<0,002$ \\
\hline Besi & $\mathrm{mg} / \mathrm{l}$ & 1 & 0,02 & $<0,03$ & $<0,02$ \\
\hline Flourida & $\mathrm{mg} / \mathrm{l}$ & 1,5 & 0,3 & 0,1 & 0,05 \\
\hline Kadmium & $\mathrm{mg} / \mathrm{l}$ & 0,005 & $<0,001$ & $<0,001$ & $<0,001$ \\
\hline Kesadahan & $\mathrm{mg} / \mathrm{l}$ & 500 & 88 & 83,2 & 100 \\
\hline Khlorida & $\mathrm{mg} / \mathrm{l}$ & 600 & 23,3 & 19,1 & 10 \\
\hline $\begin{array}{l}\text { Khromium } \\
\text { val 6 }\end{array}$ & $\mathrm{mg} / \mathrm{l}$ & 0,05 & 0,001 & $<0,004$ & $<0,004$ \\
\hline Mangan & $\mathrm{mg} / \mathrm{l}$ & 0,5 & 0,03 & 0,001 & 0,001 \\
\hline $\begin{array}{l}\text { Nitrat } \\
\text { sbg.N }\end{array}$ & $\mathrm{mg} / \mathrm{l}$ & 1 & 0,6 & 0,5 & 0,7 \\
\hline Nitrit sbg.N & $\mathrm{mg} / \mathrm{l}$ & 0,1 & 0,001 & $<0,001$ & 0,01 \\
\hline Selenium & $\mathrm{mg} / \mathrm{l}$ & 0,01 & 0,003 & 0,002 & 0,001 \\
\hline Seng & $\mathrm{mg} / \mathrm{l}$ & 15 & 0,062 & $<0,062$ & 0,1 \\
\hline Sianida & $\mathrm{mg} / \mathrm{l}$ & 1 & - & - & - \\
\hline Sulfat & $\mathrm{mg} / \mathrm{l}$ & 400 & 21,6 & 15,1 & 23,1 \\
\hline Timbal & $\mathrm{mg} / \mathrm{l}$ & 0,05 & 0,003 & 0,003 & 0,001 \\
\hline Zat organik & $\mathrm{mg} / \mathrm{l}$ & 10 & 10,1 & 6,6 & 3,2 \\
\hline sumber: Anati & & & & & 2 \\
\hline
\end{tabular}

sumber: Analisa Laboratorium Kemenkes Ditjen P3L, BTKL PP, Jakarta, 2014

Keterangan:

1. Sianida tidak diperiksa(-)

2. Baku mutu Permenkes No.416/Menkes/Per/IX/1990, 3 September 2014

\section{KESIMPULAN}

Berdasarkan penjelasan di atas maka dapat disimpulkan:

a. Teknologi pengolahan air limbah domestik dengan Membrane Bioreactor (MBR) sudah digunakan dibanyak negara karena memiliki banyak kelebihan dibanding pengolah air limbah dengan sistem konvensional, diantaranya: dapat mengolah air limbah dengan debit air limbah yang berubah-ubah, membutuhkan lahan sedikit dan hasil kualitas efluen yang sangat baik.

b. Dalam proses MBR beberapa faktor yang mempengaruhi filtrasi adalah karakteristik membran, karakteristik lumpur, jumlah oksigen yang dialirkan dan kondisi operasi.

c. Berdasarkan penelitian pengolahan air limbah dengan kombinasi pengolahan pendahuluan dengan IPAL konvensional dan pengolahan lanjutan MBR sejak 4 Maret sampai 16 Juni 2014 didapat hasil bahwa keseluruhan hasil analisa kualitas air olahan kosentrasinya memenuhi baku mutu air bersih yang ditetapkan.

d. Sesuai dengan kinerja $M B R$ yang baik tersebut maka dapat disimpulkan IPAL konvensional yang diletakkan sebelum $M B R$ juga mempunyai kinerja yang baik karena dapat menghasilkan efluen yang memenuhi standar untuk di olah di $M B R$.

e. $\quad M B R$ sebagai teknologi daur ulang air limbah mencapai hasil yang optimum jika didesain sesuai dengan desain parameter yang telah ditentukan dan dioperasikan sesuai dengan Prosedur Operasi Standar yang telah ditetapkan.

\section{DAFTAR PUSTAKA}

- $\quad$ S. Judd, The MBR book (2006) Principles and applications of membrane bioreactors in water and wastewater treatment, Elsevier, Oxford ISBN 1856174816.

- $\quad$ P. Le-Clech, V. Chen, A.G. Fane (2006). "Fouling in membrane bioreactors used in wastewater treatment". Journal of Membrane Science 284: 17. doi:10.1016/j.memsci.2006.08.019.

- Cote P, Thompson D., (2000), Wastewater treatment using membranes: the North. American experience. Water Sci. Technol. 41:209-215.

- Gupta N; Jana N; Majumder C B. (2008) Submerged Membrane Bioreactir System for Municipal Wastewater Treatment Process: An Overview, Department of Chemical Engineering, Indian Institute of Technology, India.

- Canziani, R., Em on di, V., Garavaglia, M., Malpei , F., Pasinetti, E. and Buttiglieri, G. (2006). Effect of oxygen concentration on biological nitrification and microbial kinetics in a cross-flow membrane bioreactor (MBR) and moving- bed biofilm reactor (MBBR) treating old landfill leachate. Journal of Membrane Science, 286, 202-212.

- Delgado, S.; Diaz, F.; Villarroel, R.; Vera, L.; Diaz, R.; Elmaleh, S. (2002) Influence of Biologically Treated Wastewater Quality on Filtration through a Hollow Fiber Membrane. Desalination., 146, 459.

- Chapman S, and Leslie G, Membrane Bioreactors (MBR) for Municipal Wastewater Tretament An Australian Perspective,(2001) CH2M HILL Australia Pty Ltd.

- M. Kraume, U. Bracklow, M. Vocks, A. Drews (2005). "Nutrients removal in MBRs for municipal wastewater treatment". Water science and technology: a journal of the 
International Association on Water Pollution Research 51 (6-7): 391-402. PMID 16004001.

- Malia, H. and Till, S. (2001). Membrane Bioreactors: Wastewater Treatment Applications To Achieve High Quality Effluent.
- $\quad$ (http://www.wioa.org.au/conference_papers/2 001/pdf/paper8.pdf)

- Layson, A. (2003) Microfiltration - Current Know-how and Future Directions. Memcor Technology Centre, www.usfilter.com.

Tabel 2. Perbandingan Proses Dan Tingkat Penghilan Polutan Di Proses Lumpur Aktif Dan MBR.

\begin{tabular}{|c|c|c|c|c|c|c|c|c|}
\hline & Unit & $\begin{array}{l}\text { Lumpur } \\
\text { Aktif }^{a, b, c}\end{array}$ & $\begin{array}{l}\text { MBR } \\
\mathrm{b}\end{array}$ & $\mathrm{MBR}^{\mathrm{c}}$ & $\begin{array}{l}\text { ZenoGem } \\
\text { Milton } \\
\text { (USA) }\end{array}$ & $\begin{array}{l}6 \text { Jerman } \\
750-12000 \text { EP } \\
\text { plants }^{\mathrm{e}}\end{array}$ & $\begin{array}{l}\text { BIOSEP } \\
\text { (Peran- }^{f} \\
\text { cis) }\end{array}$ & $\begin{array}{l}\text { Magnetic } \\
\text { Island } \\
\text { (Australia) }^{\mathrm{g}}\end{array}$ \\
\hline SRT & $d$ & $10-25$ & $<30$ & 30 & $>15^{\mathrm{h}}$ & $25-28$ & $>20$ & 30 \\
\hline HRT & $\mathrm{h}$ & $4-8$ & $>6$ & 8 & 3 & $<10$ & & \\
\hline MLSS & $\mathrm{kg} / \mathrm{m}^{3}$ & 5 & $\begin{array}{l}12- \\
16\end{array}$ & & $15-20$ & $\begin{array}{c}\text { 8-16, } \\
\text { Mainly } 12\end{array}$ & 15 & 15 \\
\hline $\mathrm{BOD}_{5}$ & $\begin{array}{l}\mathrm{kg} / \\
\mathrm{m}^{3} \cdot \mathrm{d}\end{array}$ & $\begin{array}{c}0,25 \\
0,32- \\
0,64\end{array}$ & & $\begin{array}{l}0,4- \\
0,7\end{array}$ & 2,5 & $0,32-0,79$ & & \\
\hline $\mathrm{BOD}_{5}(\mathrm{~F}: \mathrm{M})$ & $\begin{array}{c}\mathrm{kg} / \mathrm{kg} . \\
\mathrm{d}\end{array}$ & 0,05 & $\begin{array}{c}<0,0 \\
8\end{array}$ & & $<0,2$ & $0,02-0,066$ & & \\
\hline $\begin{array}{l}\text { Penghilangan } \mathrm{BOD}_{5} \\
\text { Konsentrasi efluen } \mathrm{BOD}_{5}\end{array}$ & $\begin{array}{c}\% \\
\mathrm{mg} / \mathrm{l}\end{array}$ & $\begin{array}{c}85-95 \\
15\end{array}$ & & $\begin{array}{l}98- \\
99\end{array}$ & $\begin{array}{l}>99 \\
<2\end{array}$ & $\begin{array}{l}98 \\
<5\end{array}$ & $.97,5$ & $<3$ \\
\hline $\begin{array}{l}\text { Penghilangan COD } \\
\text { Konsentrasi efluen COD }\end{array}$ & $\begin{array}{c}\% \\
\mathrm{mg} / \mathrm{l}\end{array}$ & 94,5 & $<30$ & 99 & & $\begin{array}{l}96,1 \\
<25\end{array}$ & 97 & \\
\hline $\begin{array}{l}\text { Penghilangan TSS } \\
\text { TSS } \\
\text { Kekeruhan }\end{array}$ & $\begin{array}{c}\% \\
\mathrm{mg} / \mathrm{l} \\
\mathrm{NTU}\end{array}$ & $\begin{array}{c}60,9 \\
10-15\end{array}$ & 0 & 99,9 & $\begin{array}{l}>99 \\
<2 \\
<0,1\end{array}$ & 0 & 99,8 & 0,6 \\
\hline $\begin{array}{l}\text { Penghilangan } \mathrm{N}_{\text {total }} \\
\text { Konsentrasi efluen } \mathrm{NH}_{4}^{+} \\
\text {Penghilangan } \mathrm{NH}_{4}^{+}\end{array}$ & $\begin{array}{c}\% \\
\mathrm{mg} / \mathrm{l} \\
\%\end{array}$ & $\begin{array}{l}<13 \\
98,9\end{array}$ & $<13$ & 99,2 & $\begin{array}{l}>96(T K N) \\
<2(\text { TKN) } \\
<0,5 \mathrm{mg} / \mathrm{l}\end{array}$ & $\begin{array}{c}92 \\
<10 \\
<1 \mathrm{mg} / \mathrm{l}\end{array}$ & $\begin{array}{c}98,6(\text { TKN } \\
\text { ) } \\
0,4(T K N)\end{array}$ & $\begin{array}{l}<2 \text { (dengan } \\
\text { dosis gula) }\end{array}$ \\
\hline $\begin{array}{l}\text { Penghilangan } \mathrm{P} \text { total } \\
\text { Konsentrasi efluen } \mathrm{P}_{\text {total }}\end{array}$ & $\begin{array}{c}\% \\
\mathrm{mg} / \mathrm{l}\end{array}$ & $\begin{array}{l}88,5 \\
0,8-1\end{array}$ & $<0,3$ & 96,6 & $\begin{array}{l}>99 \\
<0,1\end{array}$ & $\begin{array}{c}86,5 \\
1\end{array}$ & & $<0,3)$ \\
\hline
\end{tabular}

${ }^{a}$ Mudrack and Kunst, $1985,{ }^{b}$ MULNV,2003, ${ }^{\mathrm{c}}$ Cicek et.al, 1999, ${ }^{\mathrm{d}}$ Hotchkies, ${ }^{\mathrm{e}}$ Kraume and Bracklow, 2003, ${ }^{\mathrm{f}}$ TaziPain et.al., 2002, ${ }^{\mathrm{g}}$ de Haas et al., 2004, ${ }^{\text {h }}$ Mallia et al., 2001, ${ }^{\text {j }}$ Gander et.al., 2000) ${ }^{8)}$ 


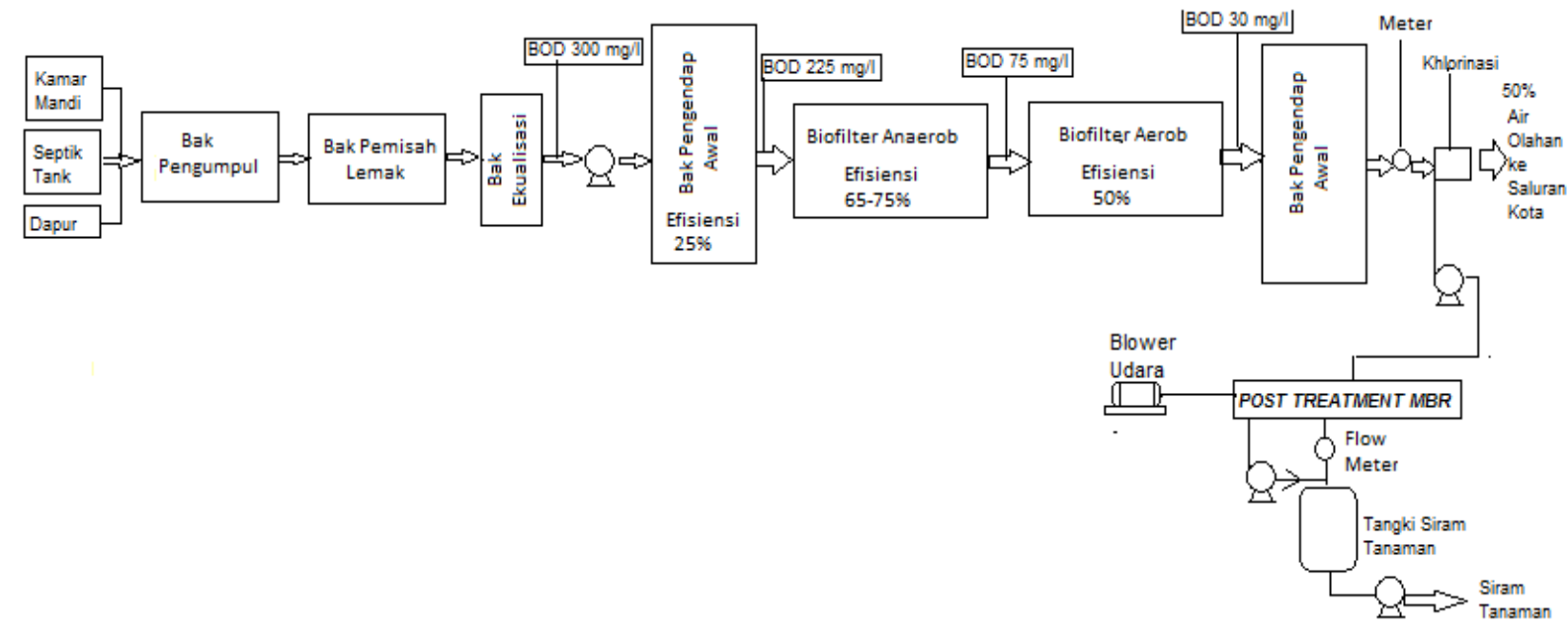

Gambar 5. Diagram Alir IPAL Dan Pengolahan Lanjutan MBR. 